\title{
The Fulfillment of Human Rights in Regional Financial Management in Indonesia
}

\author{
Ansar ${ }^{1}$ Abdul Razak ${ }^{2}$ Marthen Arie Judhariksawan $^{2}$ \\ 1.Doctoral Student, Faculty of Law, Hasanuddin University, Indonesia \\ 2.Professor of Law, Faculty of Law, Hasanuddin University, Indonesia
}

\begin{abstract}
The main challenge of political decentralization in Indonesia today is how local governments are more responsible for the full fulfillment of human rights by maximizing existing resources. For this reason, this paper proposes the use of Human Right Budgeting (HRB) for the management of financial resources in the regions in order to fulfill these rights by means of the obligation to maximize resources, the obligation of minimum allocation and the obligation of progressive realization in managing regional budgets to fulfill human rights. For this reason, the study answers several problems. First, how human rights are fulfilled in regional budgets in Indonesia, and whether local budgets have met the HRB principles, as well as what steps local governments should take in Indonesia to fulfill economic, social and cultural rights in full. In this paper, the author limits human rights only to economic, social and cultural rights, especially the right to education, the right to health, the right to food, the right to housing. To answer the above, the authors chose 6 areas as research objects, namely Bangka Belitung Islands Province, South Kalimantan Province, West Java Provinces, Malang City, Denpasar City and Palu City. There are several things that are important in this research which result in the lack of and even uncertainty regarding the full fulfillment of human rights in the regions. And finally, it is necessary to improve regulations at the national and regional levels in the effort to fulfill human rights.
\end{abstract}

Keywords: Economic, Social and Cultural Rights, Human Right Budgeting (HRB), Regional finance, Indonesia. DOI: $10.7176 / \mathrm{JLPG} / 104-02$

Publication date: December $31^{\text {st }} 2020$

\section{A. Introduction}

The main obligation of a state is to allocate resources for the well being of its citizens. This makes it obligatory for a state to prepare a budget for the full fulfillment of economic, social and cultural rights, as stated in Article 2 Paragraph (1) of the International Covenant on Economic, Social and Cultural Rights (ICESCR):

"Each State Party to the present Covenant undertakes to take steps, individually and through international assistance and co-operation, especially economic and technical, to the maximum of its available resources, with a view to achieving progressively the full realization of the rights recognized in the present Covenant by all appropriate means, including particularly the adoption of legislative measures."

The most debated topic related to the interpretation of the contents of the article above is the issue of the government's obligation to be responsible for economic, social and cultural rights with the budget, how its availability and size and the government's accountability for fulfilling its budget. Even so, resource obligations have been established progressively. However, the measurement of these obligations is still sketchy. Thus, budget allocation for the fulfillment of economic, social and cultural rights is a serious challenge for several countries. And it is also difficult to justify whether a country has fulfilled its budget obligations or not.

Meanwhile, the influence of the budget on the fulfillment of economic, social and cultural rights is very dominant, both philosophically, strategically and technically. Philosophically, as a rule of law, the fulfillment of human rights is the responsibility of the state in three ways, namely: to protect, to respect and to fulfill. The strategic role of the budget will have an impact on the fulfillment of human rights in the context of income redistribution, provision of public goods and services, and means of protection and social justice. Meanwhile, technically, the fulfillment of human rights requires substantial budget resources. In this context, the concept of Human Rights Budgeting (HRB) provides guidance on how the state is responsible for providing the budget in fulfilling full economic, social and cultural rights. HRB is a state practice that uses human rights as a standard in allocating national budgets to ensure that they fulfill their duties towards the fulfillment of human rights, while HRB will provide concrete evidence to assess the performance of the government in the presence of judicial and non-judicial mechanisms. ${ }^{1}$

So it is right to say that HRB is a tool for implementing ICESCR. With HRB; First. Ensure that key government economic policy documents are developed and implemented not only in accordance with specific government priorities, but in accordance with the human rights laws that are binding on all governments, regardless of who is in power. Second, ensure that the government gives appropriate priority in the budget for spending in

${ }^{1}$ Hien Bui, Human Rights Budgeting: Making Governments Accountable for Economic, Social and Cultural Rights, (2015) QMHRR 2(1), ISSN 2059-8092. p. 118 
key areas such as health, education, access to justice and employment; and third, Focus not only on who has access to important government goods and services, but also continuously improve the availability, accessibility and quality of these goods and services. ${ }^{1}$ According to Abdul Razak, said that as the main duty of the government is to provide public service, emerge the principle "the government must not refuse to provide public services on the grounds that there are no laws and regulations that govern it". But conversely, the government must find and provide a solution by finding the law itsel. ${ }^{2}$ Some parties divide human rights into rights groups. That is civil and political rights on the one hand, and economic, social and cultural rights on the other hand. Aside from part of the cold war influence between Western liberalism and Eastern socialist groups, this grouping is also the impact of a separate international treaty as a normative international law for the Universal Declaration of Human Rights. Principles relating to civil and political rights are normalized through the International Covenant on Civil and Political Rights (ICCPR), while on the economic and social rights of the International Covenant on Economic, Social and Cultural Rights (ICESCR). This normative of human rights is important given that the declaration has no legally binding force to bind countries. Furthermore, the ICCPR and ICESCR may only apply if the state declares a consent to be bound of the treaty. ${ }^{3}$

Ratification of the International Covenant On Economic, Social And Cultural Rights through Law No. 11 of 2005, Making the Indonesian state a Duty of Bearer which has an absolute obligation to fulfill the full fulfillment of economic, social and cultural rights. This fulfillment must be realized in the form of concrete steps, including by maximizing the use of state budget resources to fulfill economic, social and cultural rights. Affirmation of Fulfillment of the budget for the fulfillment of Economic, Social and Cultural Affairs is implicit in the legal policies for financial management in Indonesia. According to article 1 point 8 of the Local Government Act, decentralization means the transfer of Government Affairs by the central government to autonomous regions based on the principle of autonomy. The implementation of regional autonomy has led to the need for the region to develop various financial schemes to finance various shift area authority of the central government to the local government. The most frequent reason put forward is the limitations of the allocation of funds from the the central government. ${ }^{4}$ The management of state finances must be realized annually in the form of the State Opinion and Expenditure Budget (APBN) / Regional Opinion and Expenditure Budget (APBD). And the APBN and APBD clearly state that it is managed responsibly and for the greatest prosperity of the people. The law in Indonesia explicitly requires the allocation of APBD for the fulfillment of economic, social and cultural rights, demonstrating the commitment of the Indonesian state to the obligations of local governments to fulfill economic, social and cultural rights. However, from the HRB perspective there are problems in the allocation obligations mentioned above, so that there is uncertainty in the fulfillment of economic, social and cultural rights in Indonesia. how the fulfillment of economic, social and cultural rights in regional budgets in Indonesia, and whether regional budgets have met HRB principles, as well as what steps the Indonesian state should take to fulfill economic, social and cultural rights in full, for this reason, the purpose of this research is to be carried out.

\section{B. Methods of Research}

This research is a normative legal research using the statutory and conceptual approaches. The legal materials used in this research, among others, include legal regulations, international conventions, research reports, journal articles, and books. To strengthen this paper, we used stratified sampling ${ }^{5}$, which involves categorizing regions in Indonesia according to the size of their budget (APBD) before sampling; five regions were selected. This paper used the regional budgets from 2018-2020 for the sampling. We limited the research to economic, social and cultural rights, especially the budget for education, health, housing and food. We used human rights budgeting as an indicator to determine whether the APBD has fulfilled economic, social and cultural rights in Indonesia.

\section{Results and Discussion}

\section{The Position of the Regional Budget to fulfill economic, social and cultural rights in Indonesia} In the context of Economic, Social and Cultural Rights, the obligation to fully fulfill the Economic, Social and

\footnotetext{
${ }^{1}$ Miller, A. (2012). This publication presents the findings of a three year project in which the Scottish Human Rights Commission (SHRC) has reviewed research on the realisation of internationally recognised human rights in Scotland. This is not intended to be a comprehensive 'state of human rights in Scotland'report, but a prompt for discussion in the development of Scotl See the 1945 Constitution of the Republic of Indonesia. Article 23 paragraph (1)and's National Action Plan for Human Rights. p. i

${ }^{2}$ Mauliana, D., Razak, A., Arie, M., \& Patittingi, F. (2020). Discretion and Decentralization: Framing Government Policy in Regional Innovation Policies. JL Pol'y \& Globalization, 97, 30. See too, Razak, A. (2005). Kedudukan dan Fungsi Peraturan Kebijakan di Bidang Perizinan dalam Rangka Penyelenggaraan Pemerintahan. (Dissertation). Post-graduate, Hasanuddin University, p.5

${ }^{3}$ Judhariksawan. (2018). Constitutional Rights in Indonesia. International Journal of Global Community, 1(1-March), 56-68.

${ }^{4}$ Hutabalian, R., Razak, A., Arie, M., \& Ruslan, A. (2016). The Transparency of the Local Finance Management of Papua Province in the Framework of the Establishment of the Good Financial Governance. JL Pol'y \& Globalization, 48, 1.

${ }^{5}$ Stratified sampling is a sampling technique that pays attention to the levels (strata) of population elements. Population elements are divided into several levels (stratification) based on certain characteristics. In stratified random sampling, population elements are divided into groups based on their levels. The aim is to ensure that sampling is evenly distributed across all levels and that the samples represent the characteristics of all heterogeneous population elements.
} 
Cultural Rights and at the same time obliging the state to allocate a budget in its fulfillment is implied in Article 2 paragraph (1) of the ICESCR. There are several legal consequences of the article above that cause the fulfillment of these obligations. First, under the mandate of international law, upholding and fulfilling human rights is an obligation. The two principles of the agreement, namely Pacta sun servanda and Good Faith, are important principles for ensuring the fulfillment of human rights. The two principles above oblige the state to implement the principles of fulfilling human rights honestly and obeying the standards of fulfilling human rights that have been set. Second, the consequences of the word "promise" Article 2 paragraph (1) above, based on the first reason, the Indonesian state is obliged to fully realize economic, social and cultural rights by means of one of which is by providing resources, especially financial resources. Third, there is another important framework that outlines the obligations of states to fulfill economic, social and cultural rights: the so-called 'tripartite typology' According to this tripartite typology, states parties carry out three levels of duties: the obligation to respect, protect and to fulfill. Based on this framework and in particular the obligation to fulfill, the fulfillment of economic, social and cultural rights through budgetary resources can be understood as mandatory legal requirements for the state. The failure of a country to fulfill its rights can be compared to its failure to take appropriate action, including budget-related manners. Therefore, the use of budgetary measures is a legal requirement imposed on state parties. ${ }^{1}$

Fourth, the fulfillment of human rights, especially economic, social and cultural rights by the state requires enormous resources, it can be said that without resources (one of which is financial) it is certain that the economic, social and cultural rights of citizens cannot be fulfilled, so that the provision a number of budgets for the fulfillment of human rights above are mandatory. Fifth, Indonesia's national law emphasizes the importance of allocations for the fulfillment of human rights, for example; The 1945 Constitution of the Republic of Indonesia in Article $31^{2}$, article $34^{3}$, article $28 \mathrm{I} .{ }^{4}$ In addition, the obligation to allocate regional budgets in the fulfillment of Economic, Social and Cultural Rights is spread out in several provisions of the Law. ${ }^{5}$ Each year this obligation must be manifested in a regional regulation on the Regional Revenue and Expenditure Budget (APBD).

The five points above emphasize the importance of the position of the regional government budget in fulfilling economic, social and cultural rights. In Indonesian financial law, the position of the regional budget (APBD) ${ }^{6}$ has an important role in achieving full fulfillment of economic, social and cultural rights, because Regional Expenditures are prioritized for carrying out government affairs. Regional expenditure is also a means of information for the public regarding the implementation of development which at the same time can be used as a means of control and accountability for government performance. So, to see in detail how regions are committed to fulfilling economic, social and cultural rights, and how to allocate and distribute human rights budgets, we can see them in the APBD document.

\section{The position of the principles of Human Rights Budgeting (HRB) in the fulfillment of economic,} social and cultural rights.

\section{a. The Legal Position of Human Rights Budgeting}

Human Rights Budgeting (HRB) is not mentioned in the international legal framework ${ }^{7}$, So that scholars have so far claimed that the use of $\mathrm{HRB}$ as a tool of economic, social and cultural rights is only a recommendation.

\footnotetext{
${ }^{1}$ Hien Bui. Op.Cit p. 118 .

2 Article 31 paragraph (2) "Every citizen is obliged to attend basic education and the state is obliged to finance it". Article 31 paragraph (4), "The state prioritizes the education budget budget of at least twenty percent of the state revenue and expenditure budget as well as from the regional income and expenditure budget to meet the needs of the provision of national education."

${ }^{3}$ Article 34 paragraph (3) "The state is responsible for the provision of proper health service facilities and public service facilities".

${ }^{4}$ Article 28 I paragraph (4) and (5). "Protection, advancement, enforcement and fulfillment of human rights are the responsibility of the state, especially the government; and to uphold and protect human rights in accordance with the principles of a democratic rule of law, the implementation of human rights is guaranteed, regulated, and set forth in statutory regulations. "

5 There are seven laws that specifically require the provision of a budget for the fulfillment of human rights: First, Law No. 39/2009, which clearly states that children with disabilities, the elderly, have the right to education and training at state expense. Second, Law No. 20 of 2003 , which requires a 20 percent budget for education both at the regional and central levels. Third, Law No. 18 of 2012 ; Article 18 states four government obligations in terms of food fulfillment, one of which is the obligation to make budget allocations. Fourth, Law No. 29 of 2009 ; there are two articles that emphasize the obligations of the central and local governments in allocating budgets: Article 45 concerns the obligation to finance environmental protection and management activities and environmentally friendly development programs. Fifth, Law No. 24 of 2007, which emphasizes in Article 6 the government's obligations in disaster management, one of which is the provision of disaster management allocation in the form of ready-to-use funds. Sixth, Law No. 36 of 2009 , which requires a budget allocation of $5 \%$ for the fulfillment of health affairs for the central government and 10\% for local governments. Seventh, Law No. 23 of 2002. In Article 53, there are two government responsibilities in child protection, namely providing education costs and / or free assistance or special services for children from underprivileged families, neglected children, and children who live in remote areas and providing funds for implementing child protection. ${ }^{6}$ Law No. 17 of 2003 is the regional Annual Financial Plan approved by the Regional People's Representative Council. In Article 298 Regional Expenditures are prioritized for funding Compulsory Government Affairs related to Basic Services which are stipulated with a minimum service standard. (2) Regional expenditure as referred to in paragraph (1) shall be guided by technical standards and regional unit price standards in accordance with the provisions of laws and regulations. (3) Regional spending for funding of Government Affairs which becomes the authority of the Region other than those referred to in paragraph (1) shall be guided by the analysis of regional expenditure standards and standard unit prices in accordance with the provisions of the statutory regulations..

${ }^{7}$ Blyberg, A. (2012). Government Budgets and Rights Implementation: Experience from Around the World. J. Heymann J. and A. Cassola (eds), Making Equal Rights Real. p.21.
} 
Nonetheless, arguments for the legality of HRB can be placed under two main pillars. The first is the rules regarding the interpretation of the treaty provisions stipulated in the Vienna Convention on Treaty Law. Second is a function of the General Comments of the Committee on Economic, Social and Cultural Rights (CESCR).

Article 31 of the Vienna Convention on the Law of Treaties, gives the HRB legal status as a requirement of a legal obligation because its application is 'interpreted in good faith' that is, a treaty must be interpreted in good faith according to the usual meaning to be given to the term agreement in its context and in the light of the object and the goal. HRB fulfills both of these conditions. In relation to the objectives of the ICESCR, the use of HRB is to protect and promote economic, social and cultural rights and also HRB guides the state to the obligations regulated in the ICESCR. In this case, HRB specifically focuses on the task of the state so that the budget is in accordance with the realization of economic, social and cultural rights. The legal standing of the HRB can be increased through the Committee's General Comments. comments issued by the Committee are not legally binding on the state. however, what status the Committee on economic, social and cultural rights demands of States parties (through its general comments) remains to be applied as a State obligation. At this point, the Magdalena Sepulveda argues that although the Committee's interpretations may not have legally binding status, there is no doubt that they have considerable legal weight. Conway Blake, Mira Dutschke, Eoin Rooney, Aoife Nolan, Rory O'Connell and Colin Harvey went a step further than Sepulveda when they argued that the General Commentary by the committee on economic, social and cultural rights had a law-making function. and in this context HRB should not be seen as a recommendation only, but as a state legal obligation.

\section{b. Principles in the Human Rights Budgeter (HRB).}

To determine the steps to fulfill economic, social and cultural rights, the state must be guided by a number of principles for the fulfillment of human rights, specifically the fulfillment of human rights in budget management, several principles were found, namely; First, the Principle of Maximum Avilable Resourses (MAR) Obligations, namely that the government must do all it can to mobilize resources at home and abroad in order to have funds available to progressively realize the fulfillment of economic, social and cultural rights. ${ }^{1}$ MAR is also defined as the obligation that a country spends as much of its budget as possible to make economic, social and cultural rights manifest. ${ }^{2}$ The MAR principle also emphasizes that the budget must be managed effectively and efficiently. That is, wasteful spending is a failure to maximize the use of available resources (MAR), and the impact of spending must be such as to actually help realize economic, social and cultural rights. The inefficiency and ineffectiveness of implementing the available resources for the full fulfillment of economic, social and cultural rights means failure to implement the agreement.

The Indonesian Constitution is in line with the MAR Principles. There are at least two articles in the 1945 Constitution which emphasize the obligation of resources to be aimed at the greatest possible prosperity of the people. First, in the 1945 Constitution Chapter of Finance which emphasizes the budget to be managed openly and responsibly for the greatest prosperity of the people. ${ }^{3}$ Second, Chapter XIV of the National Economy and Social Welfare, which emphasizes the management of natural resources for the maximum welfare of the people. ${ }^{4}$ In technical law, orders to carry out MAR obligations are described in various regulations. The order to make maximum use of resources is defined as Priority, namely; Whereas regional budgets must be prioritized for more important affairs or Mandatory Government Affairs related to Basic Services which are determined with minimum service standards. ${ }^{5}$ How much government compliance with the MAR principle obligations can be seen from the structure of the APBD budget. For example by viewing or comparing expenditures related to economic, social and cultural rights (ESCR) with expenditures on areas not related to ESCR, or comparing intergovernmental spending on economic, social and cultural rights. ${ }^{6}$

Second, the Principle of Minimum Core Obligations. The more specific minimum core obligations are outlined in several General Comments ${ }^{7}$. This principle seeks to establish minimum legal content for uncertain economic and social rights claims ${ }^{8}$. The Minimum Core Obligations have become one of the most important conditions paving the way for the fulfillment of socio-economic rights. Even Tasioulas emphasized that the

\footnotetext{
${ }^{1}$ https://www.right-to-education.org/monitoring/content/glossary-maximum-available-resources. The Right to Education Glossary: maximum available resources. Accessed on May 52020

${ }^{2}$ Human Rights Budget Work: what, Whay, How: Briefing Paper 5: Human Rights Standards and the Budget. Published September 2019 , p. 66.

${ }^{3}$ Article 23 (1): The state revenue and expenditure budget as a manifestation of the management of state finances is stipulated annually by law and implemented openly and responsibly for the greatest prosperity of the people.

${ }^{4}$ Article 33 (3): Earth and water and the natural resources contained therein shall be controlled by the state and used for the greatest prosperity of the people.

${ }^{5}$ Article 298 (1): Regional Expenditures are prioritized for funding. Compulsory Government Affairs related to Basic Services which are stipulated with minimum service standards.

UNDP. (1991). UNDP Human Development Report, Financing Human Development, http://hdr.undp.org/en/reports/global/hdr1991/chapters/. Radhika Balakrishnan, Diane Elson, James Heintz, Nicholas Lusiani. Center for Women Global Leadership, Maximum Avialable Resourse. Analitical report, Rutgers The state University of New Jersey, June 2011. P. 3 ${ }^{7}$ See ; General Comment 13 (1999) The Right to Enjoy Education, General Comment 14 (1999) The Right to the Highest Affordable Standard of Health International Covenant on Economic, Social and Cultural Rights, General Comment No. 12, Right to Proper Food Ingredients.

${ }^{8}$ Young, K. G. (2008). The minimum core of economic and social rights: a concept in search of content. Yale J. Int'l L., 33 , p. 114.
} 
minimum core obligations are a sub set of obligations for the fulfillment of economic, social and cultural rights. ${ }^{1}$ This principle is important because it aims to avoid complacency of states in realizing socio-economic rights based on the rhetorical basis of "progressive realization". The Principle of Minimum Core Obligations establishes a foundation on which the State / Government cannot justify failure to fulfill the most essential level of socioeconomic rights. ${ }^{2}$

In the regional Financial Management system in Indonesia, the Principle of Minimum Core Obligations above is translated into the application of Minimum Service Standards (SPM) aimed at efforts to accelerate the realization of community welfare or people's welfare by using the principle of equity and justice, one of which is realized through the determination and application of $\mathrm{SPM}^{3}$. SPM is a provision regarding the types of basic services and quality of basic services that every citizen is entitled to at a minimum. ${ }^{4}$ Budget Allocation The minimum core obligations have actually been implemented in the Indonesian budgeting system, especially in the education budget ${ }^{5}$ and health ${ }^{6}$.

Third, the Principle of Progressive Realization Obligations. In his sense, the term "progressive" means "to make a continuous progression.". Thus, the progressive realization of economic, social and cultural rights requires States to take continuous steps to achieve these rights in full. For the purpose of fulfilling this, the state must move 'as quickly and effectively as possible'. ${ }^{7}$ This principle is to answer the constraints on the amount of resources needed by a country in the full fulfillment of economic, social and cultural rights. Two things are important in this principle, First, the fulfillment of full economic, social and cultural rights must be carried out gradually, as well as affirming that certain political, cultural and economic conditions cannot be accepted as an excuse or justification for failing to have a full direct impact on economic, social and cultural rights. ${ }^{8}$ Second, the obligation not to take backward steps in any case, Reduce the quality of the public budget For the fulfillment of human rights it cannot be justified, budget reduction is the last step and is complemented by adequate compensation measures aimed at protecting people who harmed by this reduction. ${ }^{9}$ The description of the fulfillment of economic, social and cultural rights in stages in detail is also applied in various general comments, for example the fulfillment of the right to free basic education ${ }^{10}$, the right to adequate food $^{11}$, right to water ${ }^{12}$ and proper sanitation ${ }^{13}$, Right to Work ${ }^{14}$, housing rights and others. The obligation to "achieve progressively" the full realization of rights has two meanings, namely; First, the obligation to continue to improve conditions. ${ }^{15}$ Second, the obligation not to take deliberate steps backwards in any way. ${ }^{16}$

\section{The Fulfillment of Human Rights in Regional Financial Management in Indonesia}

The author uses the HRB principle to answer whether regional financial management in Indonesia has made efforts to fulfill human rights in full. The author uses 3 HRB principles, as a knife for APBD analysis in 2018-2020. The results of the author's search on regional financial management are as follows;

\footnotetext{
${ }^{1}$ Dutschke, M., Nolan, A., O'Connell, R., Harvey, C., \& Rooney, E. (2010). Budgeting for Economic and Social Rights: A Human Rights Framework. Available at SSRN 1695955.

${ }^{2}$ General Comment No. 3 Characteristics of the Obligations of States to Members of the United Nations Committee on Economic, Social and Cultural Rights

${ }^{3}$ According to Article 1 number 1 Government Regulation no. 02 of 2018 concerning Guidelines for the Formulation and Implementation of Minimum Service Standards Minimum Service Standards, hereinafter abbreviated as SPM, are provisions regarding the types and quality of basic services which are mandatory regional affairs that every citizen is entitled to at a minimum.

${ }^{4}$ Article 11 paragraph (4) and Article 14 paragraph (3) Law No. 32 of 2014

${ }^{5}$ Article 31 paragraph (4) of the 1945 Constitution; The state prioritizes the education budget for at least twenty percent of the state revenue and expenditure budget as well as from the regional income and expenditure budget to meet the provision of national education.

6 Undang-undang Nomor 36 tahun 2009 tentang Kesehatan Pasal 171 (2) Besar anggaran kesehatan pemerintah daerah provinsi, kabupaten/kota dialokasikan minimal 10\% (sepuluh persen) dari anggaran pendapatan dan belanja daerah di luar gaji.

${ }^{7}$ CESCR, General Comment No 3.

${ }^{8}$ United Nations, (2017). High Commissioner for Human Rights (OHCHR)., Realizing Human Rights Through Government Budgets, York and Geneva, p. 28

${ }^{9}$ Ibid. p. 29

${ }^{10}$ General Comments Number 11 (1999) Action plan for basic education (Article 14 International Covenant on Economic, Social and Cultural Rights), paragraph 1

${ }^{11}$ General Comment Number 12, Rights to Decent Food Materials, United Nations Committee for Economic, Social and Cultural Rights E/C.12/1999/5, in paragraph 6

${ }^{12}$ General Comment 15, Rights to Water, United Nations Committee for Economic, Social and Cultural Rights, E / C.12 / 2002/11 November 26, 2002. Paragraph 17.

${ }^{13}$ General Comment 15, Right to Water, United Nations Committee for Economic, Social and Cultural Rights, E/C.12/2002/11 November 26th, 2002. Paragraph 29.

${ }^{14}$ General Comment 18, Rights to Work, Adopted on 24 November 2005, Article 6 of the International Covenant on Economic, Social and Cultural Rights. Paragraph 19.

${ }^{15}$ United Nations, High Commissioner for Human Rights (OHCHR), Realizing Human Rights through Government Budgets, York and Geneva, 2017 , p. 28.

${ }^{16}$ Ibid. p. 29
} 
a) Inefficient and effective local budget management

In HRB, acts of ineffectiveness and ineffectiveness in the budget are the same as failure to maximize the use of available resources, whereas failure to implement available resources to the full fulfillment of economic, social and cultural rights means failure to implement agreements. The above failures occurred in almost all areas which were the object of research. The failures occurred in the form of inefficient allocations and ineffective distribution of the APBD budget.

The author describes the pattern of inefficiency and ineffectiveness of regional budgets in Indonesia as follows; (a). budget ineffectiveness occurs because local governments budget very high costs for personnel costs while at the same time budgeting far less on program spending, (b). Budget inefficiency occurs because local governments budget very high costs for certain (unnecessary) inputs and vice versa, very low budgeting for certain inputs needed, (c). The impression is that local governments are budgeting unnecessary and repetitive items.
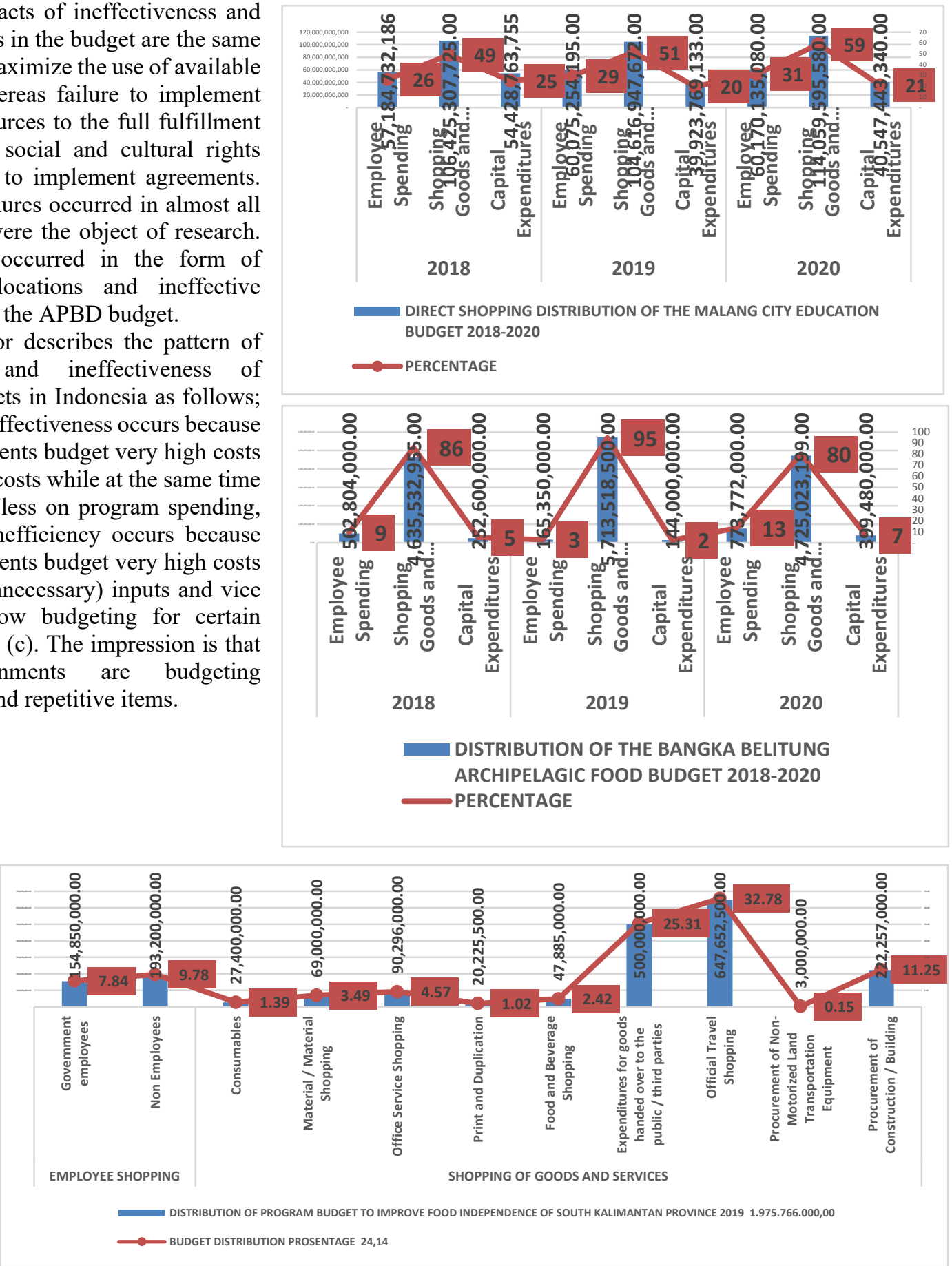

For this case, the author takes several examples of the ineffective distribution of the education budget in Malang City ${ }^{1}$ and the Food budget in the Province of Bangka Belitung Islands. ${ }^{2}$ For the last three years; capital expenditure (which should have been a larger share) in education receives a very small share. Meanwhile, the personnel expenditure budget gets a large portion. And the tendency of capital expenditures to decrease every year

\footnotetext{
${ }^{1}$ See, Regional Regulation Number 7 of 2017 concerning the City of Malang Regional Revenue and Expenditure Budget in 2018 , Regional Regulation Number 6 of 2018 concerning Malang City Regional Revenue and Expenditure Budget in 2019 and Regional Regulation Number 10 of 2019 concerning Malang City Regional Revenue and Expenditure Budget in 2020.

${ }^{2}$ See, Regional Regulation Number 15 of 2017 concerning the Regional Revenue and Expenditure Budget of the Province of Bangka Belitung Islands in 2018, Regional Regulation Number 10 of 2018 concerning the Regional Revenue and Expenditure Budget of the Province of Bangka Belitung Islands in 2019 and Regional Regulation Number 13 of 2019 concerning Regional Expenditure of Bangka Belitung Islands Province in 2020 .
} 
and vice versa in personnel spending each year has increased. The same pattern occurs in the Food budget in the Province of Bangka Belitung Islands.

In the management of the food budget in South Kalimantan Province in 2019. Budget Management in the Food Self-Reliance Improvement Program and the food diversification program for the people of South Kalimantan Province in $2019^{1}$. Both of these programs, there is an ineffective distribution of the budget, greater program spending is used for apparatus spending, while capital expenditure only gets a very small ration, below $10 \%$, even for food diversification programs capital expenditure is only $0 \%$. The pattern of ineffectiveness and inefficiency above is almost the same in all regions in Indonesia, especially those that are the object of the author's research. The above matters are both a threat and a challenge for local governments in fulfilling their full economic, social and cultural rights.

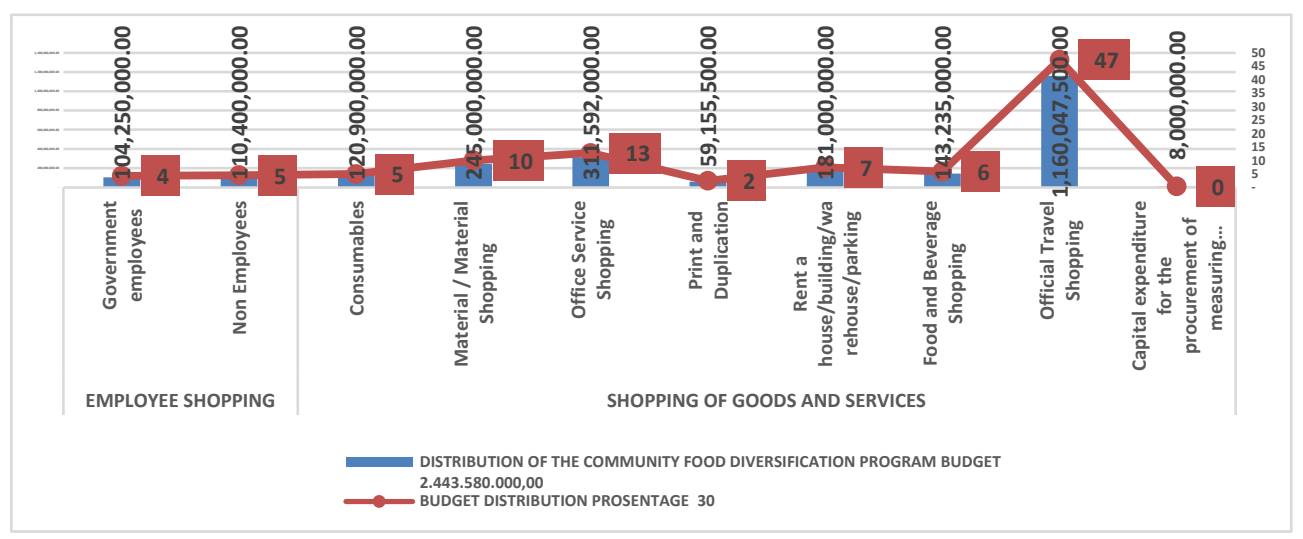

b) Non-Progressive Regional Budget Management

Above, it has been explained that the position of the principle of the obligation to progressive realization is to answer the constraints of the amount of resources needed by a country in fulfilling its economic, social and cultural rights in full, by fulfilling it gradually and not taking backward steps in any way. in this way the condition of economic, social and cultural rights increases every year. The decentralized system in Indonesia has had a good impact on regional financial conditions in Indonesia. That is; budget which increases greatly every year. However, the increase in the quantity of the regional budget has no effect on increasing the quality of the budget for the fulfillment of economic, social and cultural rights.

In the following, the authors describe the development of the budget for economic, social and cultural rights in 5 regions in Indonesia in 2018-2020;

\begin{tabular}{|c|c|c|c|c|c|c|c|c|c|}
\hline \multicolumn{10}{|c|}{ BUDGET DEVELOPMENT IN REGIONAL EDUCATION } \\
\hline & \multirow[b]{2}{*}{ Area } & \multicolumn{8}{|c|}{ TOTAL BUDGET } \\
\hline No. & & $\begin{array}{c}\text { EDUCATION } \\
\text { BUDGET } \\
2017\end{array}$ & $\%$ & $\begin{array}{c}\text { EDUCATION } \\
\text { BUDGET } \\
2018\end{array}$ & $\%$ & $\begin{array}{l}\text { EDUCATION } \\
\text { BUDGET } \\
2019\end{array}$ & $\%$ & $\begin{array}{c}\text { EDUCATION } \\
\text { BUDGET } \\
2020\end{array}$ & $\%$ \\
\hline 1 & $\begin{array}{l}\text { BANGKA BELITUNG ARCHIPELAGO } \\
\text { PROVINCE }\end{array}$ & & & 519.870 .491 .327 & 12 & 293.790 .982 .862 & 14 & 235.551 .646 .618 & 11 \\
\hline 2 & SOUTH KALIMANTAN PROVINCE & & & 928.097 .989 .084 & 15 & 1.282 .401 .211 .552 & 18 & 1.475 .992 .948 .002 & 19 \\
\hline 3 & MALANG CITY & & & 580.402 .669 .225 & 28 & 539.679 .418 .581 & 24 & 515.349 .324 .905 & 19 \\
\hline 4 & PALU CITY & & & 324.102 .387 .762 & 23 & 376.277 .894 .090 & 27 & 361.717 .168 .148 & 16 \\
\hline 5 & DENPASAR CITY & 426.373 .035 .489 & 17 & 479.665 .718 .869 & 20 & 487.668 .540 .308 & 21 & & \\
\hline
\end{tabular}

\begin{tabular}{|c|c|c|c|c|c|c|c|c|c|}
\hline \multicolumn{10}{|c|}{ BUDGET DEVELOPMENT IN REGIONAL HEALTH } \\
\hline \multirow[b]{2}{*}{ No. } & \multirow[b]{2}{*}{ Area } & \multicolumn{8}{|c|}{ TOTAL BUDGET } \\
\hline & & $\begin{array}{l}\text { HEALTH BUDGET } \\
2017\end{array}$ & $\%$ & $\begin{array}{c}\text { HEALTH } \\
\text { BUDGET } \\
2018 \\
\end{array}$ & $\%$ & $\begin{array}{l}\text { HEALTH BUDGET } \\
\text { N } 2019\end{array}$ & $\%$ & $\begin{array}{l}\text { HEALTH BUDGET } \\
2020 \\
\end{array}$ & $\%$ \\
\hline 1 & $\begin{array}{l}\text { BANGKA BELITUNG } \\
\text { ARCHIPELAGO PROVINCE }\end{array}$ & & & 279.273.539.933 & 12 & 293.790.982.862 & 14 & 235.551 .646 .618 & 11 \\
\hline 2 & SOUTH KALIMANTAN PROVINCE & & & 907.100 .474 .514 & 19 & 1.013 .752 .919 .263 & 18 & 1.086 .404 .802 .905 & 18 \\
\hline 3 & MALANG CITY & & & 191.344 .666 .750 & 16 & 215.175 .778 .902 & 16 & 334.947 .938 .110 & 19 \\
\hline 4 & PALU CITY & & & 138.673 .560 .306 & 16 & 237.296 .468 .936 & 28 & 259.702 .233 .909 & 15 \\
\hline 5 & DENPASAR CITY & $278.960 .593 .096,00$ & 22 & 328.501 .982 .626 & 22 & 353.325 .783 .862 & 23 & & \\
\hline
\end{tabular}

\begin{tabular}{|c|c|c|c|c|c|c|c|c|c|}
\hline \multicolumn{10}{|c|}{ DEVELOPMENT OF INCREASING THE REGIONAL HOUSING BUDGET } \\
\hline \multirow[b]{2}{*}{ No. } & \multirow[b]{2}{*}{ Area } & \multicolumn{8}{|c|}{ TOTAL BUDGET } \\
\hline & & $\begin{array}{c}\text { HOUSING } \\
\text { BUDGET IN } 2017 \\
\end{array}$ & $\%$ & $\begin{array}{c}\text { HOUSING } \\
\text { BUDGET IN } 2018 \\
\end{array}$ & $\%$ & $\begin{array}{c}\text { HOUSING } \\
\text { BUDGET IN } 2019 \\
\end{array}$ & $\%$ & $\begin{array}{c}\text { HOUSING } \\
\text { BUDGET IN } 2020 \\
\end{array}$ & $\%$ \\
\hline 1 & $\begin{array}{l}\text { BANGKA BELITUNG ARCHIPELAGO } \\
\text { PROVINCE }\end{array}$ & & & 30.005 .729 .555 & 1 & 21.864.669.094 & 1 & 29.692.321.356 & 1 \\
\hline 2 & SOUTH KALIMANTAN PROVINCE & & & 46.682 .355 .000 & 1 & 38.452 .482 .000 & 1 & 37.635 .680 .750 & - \\
\hline 3 & MALANG CITY & & & 95.784 .669 .100 & 5 & 98.711 .815 .740 & 4 & 40.118 .824 .343 & 1 \\
\hline 4 & PALU CITY & & & 86.625 .705 .245 & 6 & 48.620 .436 .035 & 3 & 72.905 .084 .570 & 3 \\
\hline 5 & DENPASAR CITY & 26.219 .936 .140 & 1 & 35.080 .754 .594 & 1 & 37.558 .206 .430 & 2 & & \\
\hline
\end{tabular}

\footnotetext{
${ }^{1}$ See, Regional Regulation Number 18 of 2018 concerning the Regional Budget of South Kalimantan Province in 2019.
} 


\begin{tabular}{|c|c|c|c|c|c|c|c|c|c|}
\hline \multicolumn{10}{|c|}{ DEVELOPMENT OF INCREASING THE REGIONAL FOOD BUDGET } \\
\hline \multirow[b]{2}{*}{ No. } & \multirow[b]{2}{*}{ Area } & \multicolumn{8}{|c|}{ TOTAL BUDGET } \\
\hline & & $\begin{array}{l}\text { FOOD BUDGET } \\
\text { IN } 2017\end{array}$ & $\%$ & $\begin{array}{l}\text { FOOD BUDGET } \\
\text { IN } 2018\end{array}$ & $\%$ & $\begin{array}{l}\text { FOOD BUDGET } \\
\text { IN } 2019\end{array}$ & $\%$ & $\begin{array}{l}\text { FOOD BUDGET } \\
\text { IN } 2020\end{array}$ & $\%$ \\
\hline 1 & $\begin{array}{l}\text { BANGKA BELITUNG ARCHIPELAGO } \\
\text { PROVINCE }\end{array}$ & & & 9.871 .182 .267 & 0 & 11.886 .983 .426 & - & 11.427 .709 .885 & - \\
\hline 2 & SOUTH KALIMANTAN PROVINCE & & & 86.816 .945 .050 & 1 & 91.394 .914 .984 & 1 & 108.317 .476 .992 & 1 \\
\hline 3 & MALANG CITY & & & 1.391 .095 .000 & 0 & 1.092 .778 .000 & - & 14.280 .736 .249 & 1 \\
\hline 4 & PALU CITY & & & 61.470 .630 .334 & 4 & 34.776.488.074 & 2 & 27.159 .386 .443 & 1 \\
\hline 5 & DENPASAR CITY & 12.994 .079 .700 & 0 & 13.791 .623 .612 & 1 & 13.340 .403 .890 & 1 & & \\
\hline
\end{tabular}

The above explanation shows that the management of regional budgets in Indonesia is not in line with the values contained in the convention on economic, social and cultural rights, namely the convention's demand for an increase in resource allocation every year. Two points indicate this mismatch. First, the budget for economic, social and cultural rights in the 5 regions above, does not show progressivity, that is, there is no consistent increase every year in the budgeting for economic, social and cultural rights and there is a decrease in the budget for certain economic, social and cultural rights affairs. The consistent decline in budgets was evident in the housing and food budgeting. This reduction in the budget should not have occurred, because, first, in the last 3 years there has been a continuous increase in the budget and secondly, when the budgeting process did not occur in a crisis situation in the regions.

\section{c) Contrary to the principle of minimum core obligation.}

The national budget is very important when we analyze the realization of economic, social and cultural rights, because the national budget is the main political document that reflects the priority of state policies as well as the level of public resources. In this context, the author acknowledges that regional financial regulations in Indonesia are not sufficiently supportive in affirming the provision of a budget for the fulfillment of human rights, especially in determining the minimum core obligations.

In this paper, the author believes that the implementation of the minimum core obligations with the aim of fulfilling economic, social and cultural rights is an obligation, and if any local government thinks outside of that, a country can be said to be failing in fulfilling human rights as a whole. In terms of the implementation of the minimum core obligations in the budget, an adequate indicative ceiling is required which is proportional to the regional capacity and as an initial step and as a basis for progressive steps in the fulfillment of Human Rights.

Budget Allocation The minimum core obligations have actually been applied in the Indonesian budgeting system, especially in the education and health budget, but not for other rights such as food, labor, food, environmental housing and others. For these rights, the law only states that it is obligatory to allocate a budget, but does not specify minimum obligations, in the sense that the state does not specify minimum obligations and remain in the budget for economic, social and cultural rights, herein lies the failure of local government policies in fulfilling rights the basis. As a result, in the regions, there is a tendency of imbalance in the fulfillment of one economic, social and cultural right with other economic, social and cultural rights. Certain economic, social and cultural rights (education / health) have an adequate budget while other economic, social and cultural rights experience a lack of budget in their fulfillment.

\begin{tabular}{|c|c|c|c|c|c|c|c|c|c|c|c|c|}
\hline \multirow{3}{*}{ Area } & \multicolumn{3}{|c|}{ Education } & \multicolumn{3}{|c|}{ Health } & \multicolumn{3}{|c|}{ Food } & \multicolumn{3}{|c|}{ Housing } \\
\hline & \multicolumn{12}{|c|}{$\%$ (Percentage) } \\
\hline & \multicolumn{3}{|c|}{ 2018-2019 } & \multicolumn{3}{|c|}{ 2018-2020 } & \multicolumn{3}{|c|}{ 2018-020 } & \multicolumn{3}{|c|}{$2018-2020$} \\
\hline Denpasar City & 20 & 21 & & 21 & 23 & & 1 & 1 & & 1 & 2 & \\
\hline Palu City & 22 & 27 & 16 & 16 & 28 & 15 & 4 & 2 & 1 & 6 & 3 & 3 \\
\hline Malang City & 28 & 24 & 19 & 15 & 16 & 19 & 0 & 0 & 1 & 4 & 4 & 1 \\
\hline Bangka Belitung Archipelago Province & 18 & 20 & 20 & 13 & 14 & 11 & - & - & 0 & 1 & 1 & 1 \\
\hline South Kalimantan Province & 15 & 18 & 19 & 19 & 18 & 18 & - & - & 0 & 0 & 1 & 0 \\
\hline
\end{tabular}

The table above shows that during the last three years, in several regions that have become the focus of the author, only 1 (one) percent of the food sector, the housing sector, the social sector, even allocated 0 (zero) percent for the budget for the fulfillment of human rights. Meanwhile, for education and health affairs, the budget is quite large (10 - 20\% of the total budget), The above imbalance is not ideal in fulfilling economic, social and cultural rights and will cause people to be unable to fully enjoy their economic, social and cultural rights. Isn't the right to health as much as possible depending on the right to food or the right to education is also related to the right to housing and others. In the sense that the fulfillment of economic, social and cultural rights must be carried out simultaneously by not prioritizing one right with another. The concept of inseparability in the fulfillment of this Right has been emphasized in the general comments of the United Nations on adequate food:

The Committee affirms that the right to adequate food is inseparable from the inherent dignity of every human being and cannot be left behind in the fulfillment of other human rights stated in the International Charter of Human Rights. This right is also inseparable from social justice, requiring the making of appropriate environmental and social economic policies, both on a national and international scale, aimed 


\section{at the eradication of poverty and the fulfillment of all human rights for all. ${ }^{1}$}

\section{d) Contrary to the Principle of Maximum Available Resources obligation}

The position of MAR as an obligation and how the indicator of the implementation of MAR has been discussed at least in the previous discussion. First, whether the regional government budget resources have met the MAR principle by looking at or comparing regional expenditures related to economic, social and cultural rights (mandatory functions) $)^{2}$ with Regional Expenditures for fields not related to economic, social and cultural rights. Second, whether the allocated budget is effective and efficient. For the first indicator, the writer chooses functions that are not related to mandatory affairs related to basic services, namely; Regional Secretariat budget management and Regional Legislative Budget to compare with the budget for economic, social and cultural rights. Meanwhile, the second indicator has been discussed in the previous discussion regarding the ineffectiveness and efficiency of regional budgets.

\begin{tabular}{|c|c|c|c|c|c|c|c|c|}
\hline \multirow{3}{*}{ Area } & \multicolumn{8}{|c|}{ Budget Development For Regional Community Councils } \\
\hline & \multicolumn{2}{|l|}{2017} & \multicolumn{2}{|l|}{2018} & \multicolumn{2}{|l|}{2019} & \multicolumn{2}{|l|}{2020} \\
\hline & Budget & $\%$ & Budget & $\%$ & Budget & $\%$ & Budget & $\%$ \\
\hline Denpasar City & 70.039 .911 .900 & 4 & 98.862 .055 .704 & 4 & 97.535 .007 .588 & 4 & & \\
\hline Palu City & & & 47.004 .449 .731 & 3 & 47.337 .790 .293 & 3 & 48.539 .658 .223 & 2 \\
\hline Malang City & & & 95.921 .831 .200 & 5 & 105.960 .475 .466 & 5 & 98.741 .639 .200 & 4 \\
\hline Bangka Belitung Archipelago Province & & & 140.134 .181 .900 & 6 & 146.047 .946 .682 & 5 & 129.461 .281 .937 & 4 \\
\hline South Kalimantan Province & & & 148.632 .610 .715 & 2 & 195.619 .256 .620 & 3 & 198.397 .400 .120 & 3 \\
\hline
\end{tabular}

If we look at the budget allocation for Government Affairs Supporting Functions of regional government, the allocation of this budget in the regions gets a very adequate budget. The table above, explains that the average annual share especially for the legislative body gets a very large portion, even though the utilization of the legislative institution's budget is only used for part of the people. The average annual budget for the Secretariat of the legislative body is $2-6 \%$. Meanwhile, the regional secretarial budgets also receive a fairly large budget, amounting to $2-4 \%$ of the total budget.

\begin{tabular}{|l|c|c|c|c|c|c|c|c|}
\hline \multirow{2}{*}{ Area } & \multicolumn{6}{c|}{ Budget Development For Regional Secretariat } \\
\cline { 2 - 8 } & \multicolumn{2}{|c|}{$\mathbf{2 0 1 7}$} & \multicolumn{2}{|c|}{$\mathbf{2 0 1 8}$} & \multicolumn{2}{c|}{$\mathbf{2 0 1 9}$} & \multicolumn{2}{c|}{$\mathbf{2 0 2 0}$} \\
\cline { 2 - 8 } & Budget & $\mathbf{\%}$ & Budget & \% & Budget & \% & Budget & \% \\
\hline Denpasar City & 79.014 .500 .662 & 4 & 81.643 .773 .252 & 3,44 & 94.511 .376 .938 & 4 & & \\
\hline Palu City & & & 39.772 .704 .094 & 3 & 37.421 .620 .024 & 3 & 38.903 .969 .125 & 2 \\
\hline Malang City & & & 20.581 .779 .100 & 1 & 22.924 .011 .394 & 1 & 28.175 .210 .200 & 1 \\
\hline Bangka Belitung Archipelago Province & & & 127.598 .209 .056 & 5 & 113.530 .027 .702 & 4 & 111.464 .326 .159 & 4 \\
\hline South Kalimantan Province & & & 91.628 .365 .740 & 2 & 110.328 .800 .000 & 1,57 & 127.486 .770 .508 & 1,68 \\
\hline
\end{tabular}

The province of the Bangka Belitung islands, from 2018-2020, for food, housing, social affairs only received a very small portion, namely $0-1 \%$, while compared to the best allocation, the DPRD Secretariat received a fairly large budget, namely $4-6 \%$ of the total budget. This allocation is not only unfair but at the same time does not make the fulfillment of human rights a priority. The allocation above, of course, contradicts the principle of MAR, which emphasizes the allocation of the maximum budget for the fulfillment of economic, social and cultural rights and makes the right of ESC rights a priority in budget allocation. ${ }^{3}$

\section{The Reconstruction of Regional Budget Policies in Fulfilling Economic, Social and Cultural Rights in Full}

The above principles are not new in the principles of regional financial management in Indonesia and in practice these principles for certain rights have been applied in Indonesian regional budget regulations, so it needs to require

${ }^{1}$ General Comment no. 12 The Right to Adequate Food Ingredients, United Nations Committee on Economic, Social and Cultural Rights. E / C.12 / 1999/5 Committee on Economic, Social and Cultural Rights, (20th Session, Geneva, 26 April - 14 May 1999 , Agenda Number 7: Substantive Issues Arising in the Implementation of the International Covenant on Rights Economic, Social and Cultural Rights: General Comment 12 (20th Session, 1999) Right to adequate food materials (Article 11).

${ }^{2}$ Government Regulation Number 12 of 2019 concerning regional financial management. The PP has emphasized the distribution of Regional expenditures to several Affairs. First, for compulsory government affairs related to basic services, the regions must prioritize their spending for the fulfillment of these affairs. Second, for compulsory government affairs that are not related to basic regional services, the regions must allocate according to regional needs. And third for Government Affairs. Regional expenditure options are allocated in accordance with regional priorities and the potential of the Region.

${ }^{3}$ Regional Regulation No. 7 of 2017 concerning the City of Malang Regional Revenue and Expenditure Budget in 2018. Regional Regulation No. 6 of 2018 concerning Malang City Regional Revenue and Expenditure Budget in 2019. Regional regulation No. 10 of 2019 concerning Malang City Regional Revenue and Expenditure Budget in 2020. Regional Regulation No. 15 of 2017 concerning the Regional Revenue and Expenditure Budget of the Province of Bangka Belitung Islands for 2018. Regional Regulation No. 10 of 2018 concerning the Regional Revenue and Expenditure Budget of the Province of Bangka Belitung Islands for 2019. Regional Regulation No. 13 of 2019 concerning the Revenue and Expenditure Budget of the Province of Bangka Belitung Islands in 2020. Regional Regulation No. 15 of 2017 concerning the Regional Budget of South Kalimantan Province in 2018. Regional Regulation No. 18 of 2018 concerning the Regional Budget of South Kalimantan Province in 2019. Regional Regulation No. 18 of 2018 concerning the Regional Revenue and Expenditure Budget of the Province of South Kalimantan in 2019. Regional Regulation No. 09 of 2016 concerning the Regional Budget for the City of Denpasar in 2017. Regional Regulation No. 06 of 2018 concerning the Regional Budget for the City of Denpasar for 2019. Denpasar Mayor Regulation No. 3 of 2018 concerning the Elaboration of Changes to the 2018 Revenue and Expenditure Budget. Regional Regulation No. 15 of 2017 concerning the City of Palu Regional Revenue and Expenditure Budget in 2018. Regional Regulation No. 6 of 2018 concerning the Regional Budget of Palu City in 2019. Regional Regulation No. 13 of 2019 concerning the 2020 Regional Budget of Palu 
a little adjustment to the regulations and their application. However, the problem is that there is no firmness and sustainability of the above principles, it is carried out partially and inconsistently. So that in terms of the fulfillment of human rights in regional financial management, the author emphasizes the inclusion of these principles into regional financial management regulations and the position of these principles can be used as a test tool for regional financial management.

According to the author, there are four things that have a big impact from incorporating these principles into regional financial management regulations and the position of these principles can be used as a test tool for regional financial management. The first is to prevent the government, especially the regional government, from ignoring it. Indonesia's challenge in the era of decentralization is the potential for major violations of economic, social and cultural rights, either deliberately or because of neglect.

Second, the major impact of the above for the development of human rights law in Indonesia is to strengthen Justiciable's position on economic, social and cultural rights. The assumption that economic, social and cultural rights are positive rights, then economic, social and cultural rights cannot be prosecuted in court (non-justiciable). In contrast, civil rights and political rights, as negative rights, can be prosecuted in court. Apart from distinguishing them in these positive and negative ways, an ideological distinction is also made. Economic, social and cultural rights are said to be ideological, while civil rights and political rights are non-ideological. This means that economic, social and cultural rights can only be applied to a particular economic system, while civil rights and political rights can be applied to any economic system or any government. This article makes the government, especially the regional government, in a condition that is obligatory and responsible for the fulfillment of economic, social and cultural rights and has legal consequences because if the article does not take fulfillment action.

Third, the big impact of the above for the fulfillment of human rights in Indonesia is the obligation for the government, especially the local government, to allocate maximum resources in fulfilling human rights. This maximum resource is the legal consequence of these two things. The allocation of resources is also the basis for assessing the government's commitment in fulfilling these rights.

Fourth, accountability, the government can be held accountable for actions in the fulfillment of human rights. The request for responsibility can be carried out politically by the parliament, legally by the court and administratively by regional head reports to the people on a regular basis at the same time as the end of the fiscal year. And also fundamentally that the community can file criminal or civil charges against the regional government due to negligence or deliberate fulfillment of economic, social and cultural rights.

\section{E. Conclusion}

International provisions make the position of regional budgets an integral part of the efforts of the state as a legal subject in the full fulfillment of human rights. International provisions have obliged and guided the state to fulfill this, by implementing several principles of resource management for the fulfillment of human rights. In the context of Indonesia, regional financial regulations at least have explicitly applied the above principles, by requiring budget allocations to fulfill the rights of economic, social and cultural and minimum obligations for the education and health budget. However, the rest is far from expectations and its implementation has not been supported by a firmer law. This has resulted in uncertainty about the fulfillment of economic, social and cultural rights in Indonesia. So it requires improvements in the field of regional financial management for sustainability and certainty of the fulfillment of human rights in the regions.

The hope is how regional financial regulations can guarantee the full fulfillment of economic, social and cultural rights, namely by radically formulating the constitution relating to state and regional finances. In this way the ideals of the international community, namely to create conditions in which all people can enjoy their economic, social and cultural rights can be realized.

\section{References}

Blyberg, A. (2012). Government Budgets and Rights Implementation: Experience from Around the World. J. Heymann J. and A. Cassola (eds), Making Equal Rights Real. https://www.right-toeducation.org/monitoring/content/glossary-maximum-available-resources. The Right to Education Glossary: maximum available resources. Accessed on May 52020.

Dutschke, M., Nolan, A., O'Connell, R., Harvey, C., \& Rooney, E. (2010). Budgeting for Economic and Social Rights: A Human Rights Framework. Available at SSRN 1695955.

Hutabalian, R., Razak, A., Arie, M., \& Ruslan, A. (2016). The Transparency of the Local Finance Management of Papua Province in the Framework of the Establishment of the Good Financial Governance. JL Pol'y \& Globalization, 48, 1.

Hien Bui, (2015). Human Rights Budgeting: Making Governments Accountable for Economic, Social and Cultural Rights, QMHRR 2(1), ISSN 2059-8092. p. 118

Human Rights Budget Work: what, Whay, How: Briefing Paper 5: Human Rights Standards and the Budget. Published September 2019. 
Hutabalian, R., Razak, A., Arie, M., \& Ruslan, A. (2016). The Transparency of the Local Finance Management of Papua Province in the Framework of the Establishment of the Good Financial Governance. JL Pol'y \& Globalization, 48, 1.

Imran, I., Bakhtiar, H. S., \& Achmad, D. (2020). Legal Standing and Authority of the Regional Representative Council in the Indonesia Constitusional System. Amsir Law Journal, 1(2), 54-60.

Judhariksawan. (2018). Constitutional Rights in Indonesia. International Journal of Global Community, 1(1March), 56-68.

Mauliana, D., Razak, A., Arie, M., \& Patittingi, F. (2020). Discretion and Decentralization: Framing Government Policy in Regional Innovation Policies. JL Pol'y \& Globalization, 97, 30.

Miller, A. (2012). This publication presents the findings of a three year project in which the Scottish Human Rights Commission (SHRC) has reviewed research on the realisation of internationally recognised human rights in Scotland. This is not intended to be a comprehensive 'state of human rights in Scotland'report, but a prompt for discussion in the development of Scotl See the 1945 Constitution of the Republic of Indonesia. Article 23 paragraph (1)and's National Action Plan for Human Rights.

Razak, A. (2005). Kedudukan dan Fungsi Peraturan Kebijakan di Bidang Perizinan dalam Rangka Penyelenggaraan Pemerintahan. (Dissertation). Post-graduate, Hasanuddin University,

United Nations, (2017). High Commissioner for Human Rights (OHCHR)., Realizing Human Rights Through Government Budgets, York and Geneva.

UNDP. (1991). UNDP Human Development Report, Financing Human Development, http://hdr.undp.org/en/reports/global/hdr1991/chapters/. Radhika Balakrishnan, Diane Elson, James Heintz, Nicholas Lusiani. Center for Women Global Leadership, Maximum Avialable Resourse. Analitical report, Rutgers The state University of New Jersey, June 2011.

Young, K. G. (2008). The minimum core of economic and social rights: a concept in search of content. Yale J. Int'l L., 33,

\section{Laws and Regulations}

The 1945 Constitution of the Republic of Indonesia

Universal Declaration of Human Rights

Law No. 39 of 1999

Law No. 17 of 2003

Law No. 20 of 2003

Law No. 24 of 2007

Law No. 36 of 2009

Law No. 18 of 2012

Law No. 23 of 2014

International Commission of Jurists (ICJ), Maastricht Guidelines on Violations of Economic, Social and Cultural Rights, 26 January 1997.

General Comment No. 13 (1999): The Right to Enjoy Education; General Comment 14 1999): The Right to the Highest Affordable Standard of Health, International Covenant on Economic, Social and Cultural Rights; General Comment No. 12: Right to Adequate Food

General Comment No. 3: Characteristics of the Obligations of States to Members of the United Nations Committee on Economic, Social and Cultural Rights (1994).

General Comment No. 11 (1999): Action plan for basic education (Article 14 of the International Covenant on Economic, Social and Cultural Rights)

General Comment No. 12: The Right to Adequate Food, United Nations Committee on Economic, Social and Cultural Rights E / C. 12/1999/5

General Comment 15: Right to Water, United Nations Committee for Economic, Social and Cultural Rights, E / C. 12 / 2002/11 26 November 2002 .

General Comment 15: Right to Water, United Nations Committee for Economic, Social and Cultural Rights, E / C.12 / 2002/1126 November 2002.

The Right to Work: General Comment 18, Adopted 24 November 2005, Article 6 of the International Covenant on Economic, Social and Cultural Rights.

General Comment No. 12: Right to adequate foodstuff, United Nations Committee for Economic, Social and Cultural Rights. E / C.12 / 1999/5 Committee on Economic, Social and Cultural Rights.

Government Regulation No. 12 Year 2019

Government Regulation No. 02 of 2018

Regional Regulation No. 7 of 2017 concerning the 2018 Regional Budget of Malang City.

Regional Regulation No. 6 of 2018 concerning the Malang City Regional Revenue and Expenditure Budget in 2019. 
Regional Regulation No. 10 of 2019 concerning the 2020 Malang City Regional Revenue and Expenditure Budget. Regional Regulation No. 15 of 2017 concerning the Regional Revenue and Expenditure Budget of the Province of Bangka Belitung Islands in 2018.

Regional Regulation No. 10 of 2018 concerning the Regional Revenue and Expenditure Budget of the Province of Bangka Belitung Islands in 2019.

Regional Regulation No. 13 of 2019 concerning the Regional Revenue and Expenditure Budget of the Province of Bangka Belitung Islands in 2020.

Regional Regulation No. 15 of 2017 concerning the Regional Budget of South Kalimantan Province in 2018

Regional Regulation No. 18 of 2018 concerning the 2019 South Kalimantan Province Regional Revenue and Expenditure Budget

Regional Regulation No. 09 of 2016 concerning the Denpasar City Regional Revenue and Expenditure Budget in 2017

Regional Regulation No. 06 of 2018 concerning the Denpasar City Regional Revenue and Expenditure Budget in 2019

Denpasar Mayor Regulation No. 3 of 2018 concerning the Elaboration of Changes to the 2018 Revenue and Expenditure Budget

Regional Regulation No. 15 of 2017 concerning the Regional Budget of Palu City in 2018

Regional Regulation No. 6 of 2018 concerning the 2019 Regional Budget of Palu City

Regional Regulation No. 13 of 2019 concerning the Palu City Regional Revenue and Expenditure Budget in 2020 